\title{
Exercise-related novel gene is involved in myoblast differentiation
}

\author{
Mitsuhiro TAKAHASHI and Shunichiro KuBOta ${ }^{1}$ \\ Department of Life Sciences, Graduate School of Arts and Sciences, The University of Tokyo, 3-8-1 Komaba, Meguro-ku, Tokyo \\ 153-8902, Japan \\ (Received 4 February 2005; and accepted 12 February 2005)
}

\begin{abstract}
In this study we tried to identify new genes or proteins in skeletal muscle induced by exercise. We analyzed alterations of protein expression in mouse gastrocnemius muscles induced by swimexercise using two dimensional gel electrophoresis and mass spectrometry. Nine spots were significantly altered between control and swim groups. One of the four protein spots whose expression was decreased was identified as functionally unknown "expressed sequence AI854635" gene. The AI854635 gene has $\mathrm{C} 2 \mathrm{H} 2$ type zinc finger motif, and is considered to be a transcription factor. The mRNA of AI854635 gene was expressed in skeletal muscle, brain, kidney, and thymus. To elucidate the function of the AI854635 gene we analyzed mRNA expression levels during $\mathrm{C} 2 \mathrm{C} 12$ myoblast differentiation. $\mathrm{C} 2 \mathrm{C} 12$ myoblast began to form myotube around $20 \mathrm{~h}$ after the initiation of differentiation. The mRNA expression levels of AI854635 gene was significantly induced around $6 \mathrm{~h}$ and increased till $48 \mathrm{~h}$, indicating a pivotal role in myoblast differentiation. Although the significance of decreased expression of AI854635 gene induced by swim-exercise is not clear, we found that this gene is involved in myoblast differentiation.
\end{abstract}

The formation of skeletal muscle during embryogenesis depends on multifactorial processes $(9,10,13$, 19). The myogenic regulatory factors (MRFs) are essential for myogenesis. The MRFs consist of MyoD, Myf-5, myogenin and MRF4. MyoD and Myf-5 play pivotal roles in myogenic determination, whereas myogenin and MRF4 are important for terminal differentiation $(4,10,11,13,15,18,19,25)$. The MRF proteins belong to a superfamily of basic helix-loop-helix (bHLH) transcription factors (12, 21). The molecular mechanism of myoblast differentiation is not fully understood. $\mathrm{C} 2 \mathrm{C} 12$ cultured cells are skeletal muscle precursor cells which have proven an excellent system to elucidate myogenic differentiation $(1,4,26)$.

Resistance or eccentric exercise activates satellite cells in mature skeletal muscle cells and induces

\footnotetext{
${ }^{1}$ Address correspondence to: Shunichiro Kubota

Tel and Fax: +81-3-5454-6869

E-mail: kubota@idaten.c.u-tokyo.ac.jp
}

differentiation leading to muscle cell hypertrophy (2, $6,17,23)$. Exercise induces several muscle gene expression including MRF protein expression $(2,17)$.

Proteomic technologies using two dimensional gel electrophoresis and mass spectrometry provide the tool to discover and identify novel genes or proteins $(3,7,14,24)$.

\section{MATERIALS AND METHODS}

Animals and exercise. C57BL/6J male mice (4 week old) were purchased from Japan SLC Co. Ltd. (Hamamatsu, Japan), and grouped to 10 control and 10 swim-exercised mice. According to Zhou's swimming protocol (28), control mice were kept sedentary and swim-exercised mice were exercised by swimming in plastic barrel $(40 \times 60 \times 30 \mathrm{~cm})$ filled with warm water $\left(35^{\circ} \mathrm{C}\right)$. Mice swam for $30 \mathrm{~min}$ periods for up to $150 \mathrm{~min}$ interrupted by $10 \mathrm{~min}$ rest periods. At 150 min, 10 mice of each group were sacrificed by cervical dislocation and gastrocnemius 
muscles were isolated for protein and total RNA extraction. Three independent experiments were performed and we confirmed the data. For proteomics analysis 10 gastrocnemius muscles (at $150 \mathrm{~min}$ ) were pooled. This study was performed according to the guidelines of The University of Tokyo and conformed with the national law for animal rights.

Protein and RNA extraction. The pooled skeletal muscles $(0.4 \mathrm{~g})$ were homogenized and extracted in $1 \mathrm{ml}$ lysis buffer [9.5 M urea, 1\% dithiothreitol, $2 \%$ 3-[(3-cholamidopropyl) dimethylammonio] 1-propanesufonate (CHAPS), 0.8\% Pharmalyte $\mathrm{pH} 3-10$ (Amersham Biosciences, Tokyo, Japan), $1 \mathrm{mM}$ phenylmethanesulfonyl fluoride (PMSF), $1 \mathrm{mM}$ ethylenediaminetetraacetic acid (EDTA), $10 \mu \mathrm{g} / \mathrm{ml}$ leupeptin, $10 \mu \mathrm{g} / \mathrm{ml}$ aprotinin]. The protein concentrations were measured using Bradford method (BioRad, Hercules, CA, USA). Total RNA was extracted using a QuickPrep Total RNA Extraction kit (Amersham Biosciences).

Proteomics analysis. Using $400 \mu \mathrm{g}$ of muscle homogenate two dimensional gel electrophoresis was performed. First, isoelectric focusing was performed using the Immobiline ${ }^{\mathrm{TM}}$ DryStrip pH3-10NL, $13 \mathrm{~cm}$ (Amersham Biosciences). Then, SDS (10\%) polyacrylamide gel electrophoresis was performed. The gels were silver-stained using PlusOne Silver Staining kit (Amersham Biosciences). Samples for matrix-assisted laser desorption ionization-time of flight (MALDI-TOF) analysis were excised from the gels. In-gel digestion of the individual protein spots was done using $12.5 \mu \mathrm{g} / \mathrm{ml}$ trypsin (Wako Pure Chemical Industry, Osaka, Japan) as described previously (3, 7, $14,24)$. The peptide solutions were vacuum-concentrated until the volume was decreased to $10 \mu 1$, and desalted using ZipTip ${ }^{\mathrm{TM}} \mathrm{C} 18$ column (Millipore, Bedford, MA, USA) according to the manufacturer's protocol. AXIMA-CFR Shimadzu model MALDITOF mass spectrometer (Shimadzu, Kyoto, Japan) was used for mass analysis for tryptic peptide mixtures.

Cell culture. $\mathrm{C} 2 \mathrm{C} 12$ myoblast was purchased from American Type Culture Collection (Manassas, VA, USA) and cultured with Dulbecco's modified Eagle's media (DMEM) containing 10\% fetal calf serum. Differentiation of $\mathrm{C} 2 \mathrm{C} 12$ cells were induced by DMEM containing $2 \%$ horse serum (4). Three independent experiments were performed.

$R T-P C R$. RT-PCR was performed using a TAKARA RT-PCR kit $\left(55^{\circ} \mathrm{C} 30 \mathrm{~min}\right.$ for RT, $94^{\circ} \mathrm{C} 30 \mathrm{~s}, 60^{\circ} \mathrm{C}$ $30 \mathrm{~s}$, and $72^{\circ} \mathrm{C} 90 \mathrm{~s}$ for PCR). The sequences of RTPCR primers and the number of PCR cycles are shown in Table 1 . The PCR products were electrophoresed on 2\% agarose gels and 100-bp ladder markers were used to compare the size of PCR products. After the gels were stained with ethidium bromide, the images were acquired using the ChemiDoc XRS image analyzer (Bio-Rad). Using the installed applications the quantity of the PCR products was measured and expressed as pixel counts.

Statistical analysis. Results obtained from triplicate experiments were shown as the mean \pm standard deviation. Significance was analyzed by Student's t-test. $\mathrm{P}<0.05$ was considered to be significant.

\section{RESULTS}

\section{Identification of protein spots on two dimensional} gels

Fig. 1A and 1B shows silver-stained gels derived from gastrocnemius muscles of controls and of swim-exercised mice (150 min), respectively. Nine spots were remarkably and differentially expressed

Table 1 RT-PCR Primers and PCR Cycles

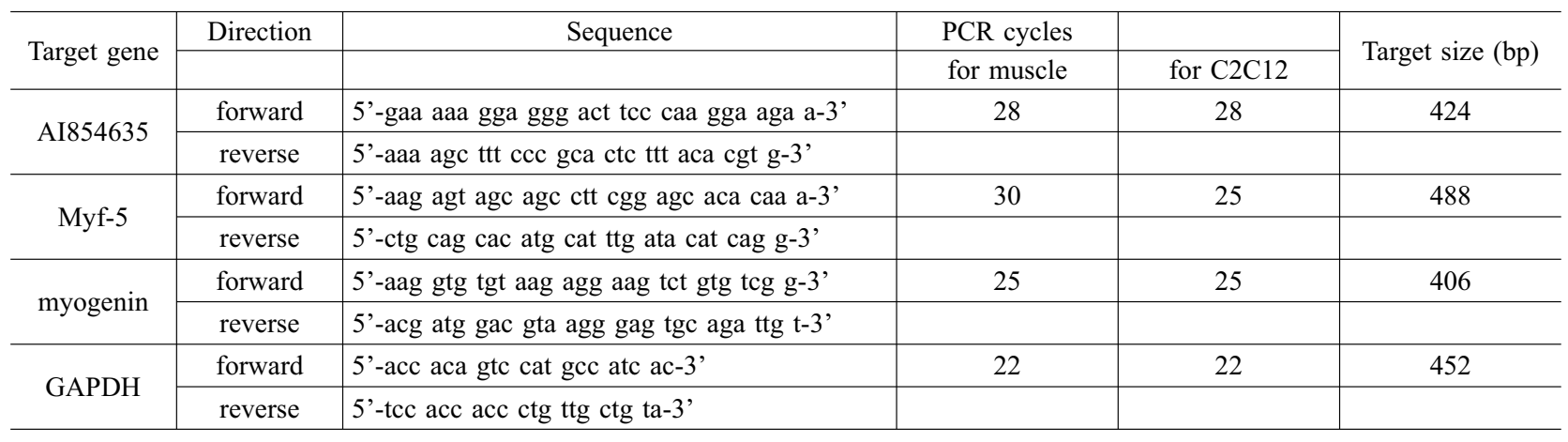




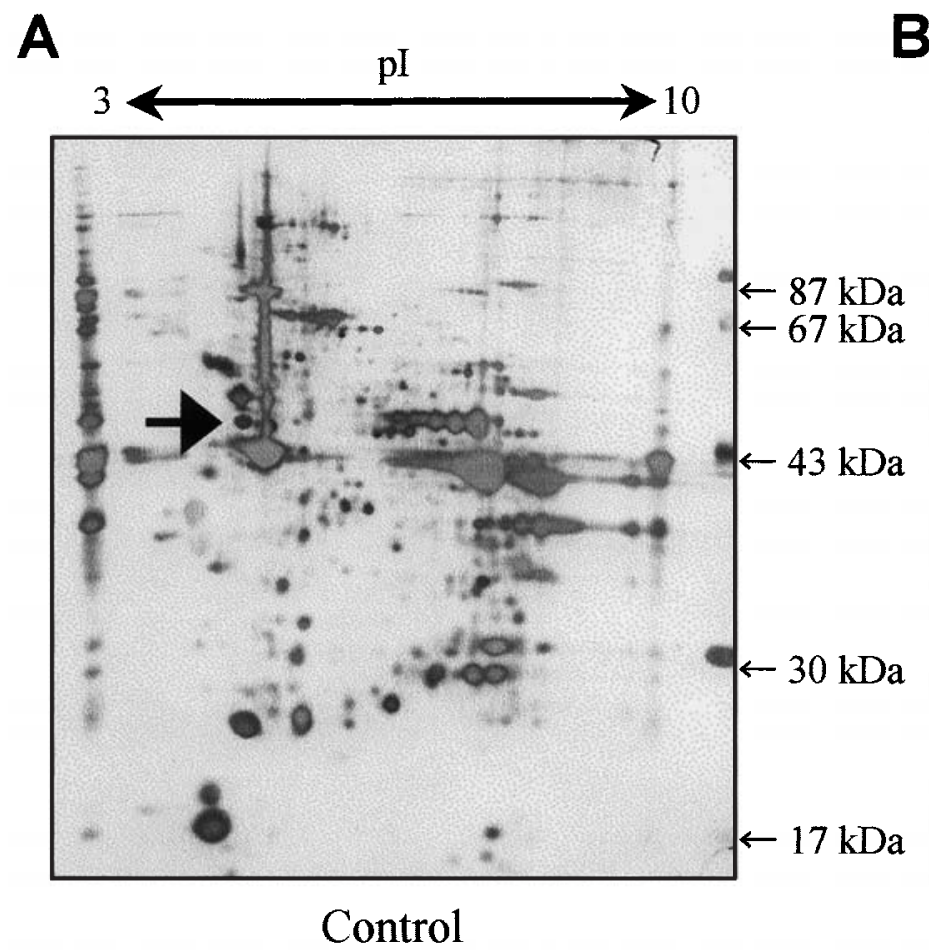

B
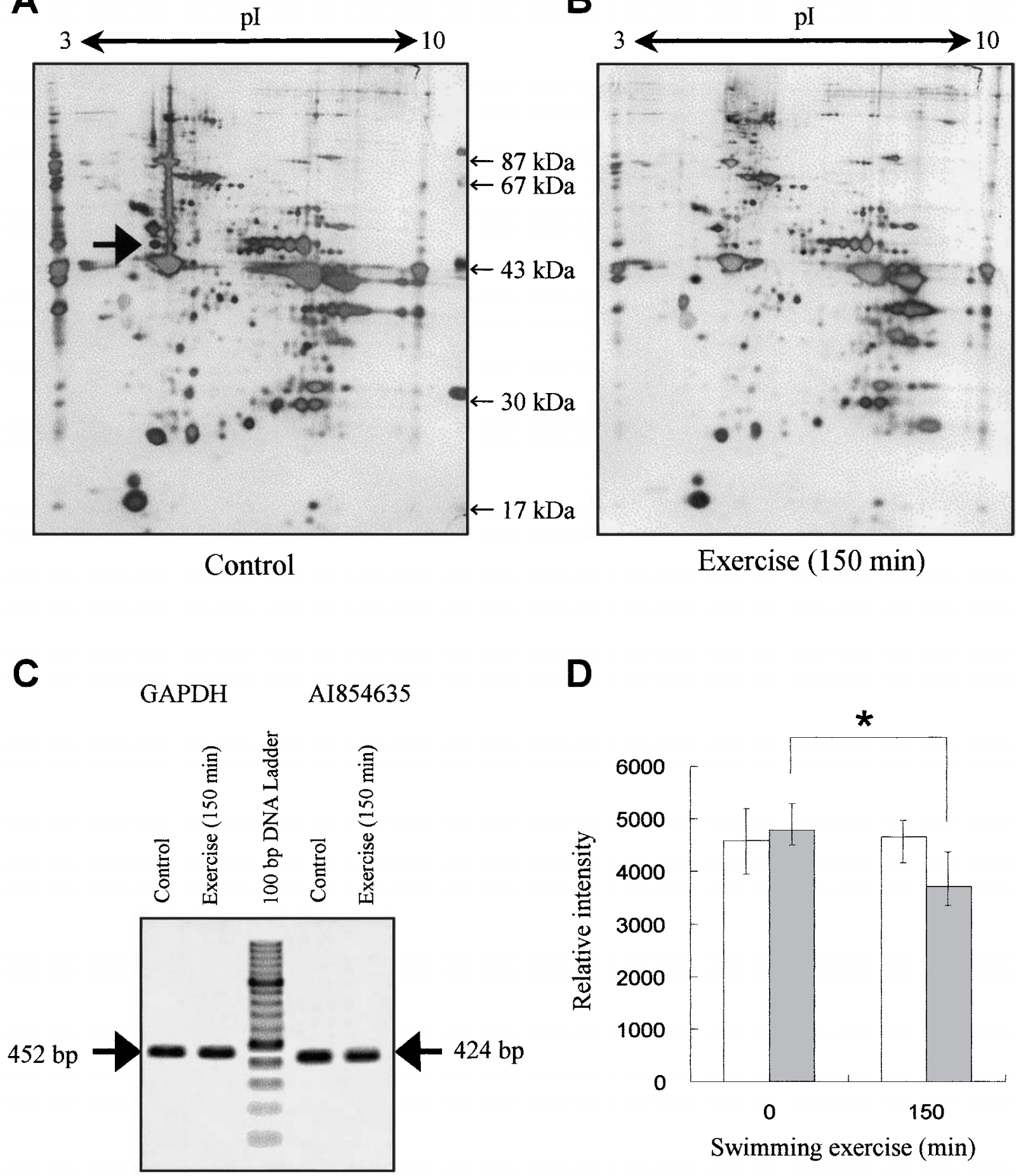

D

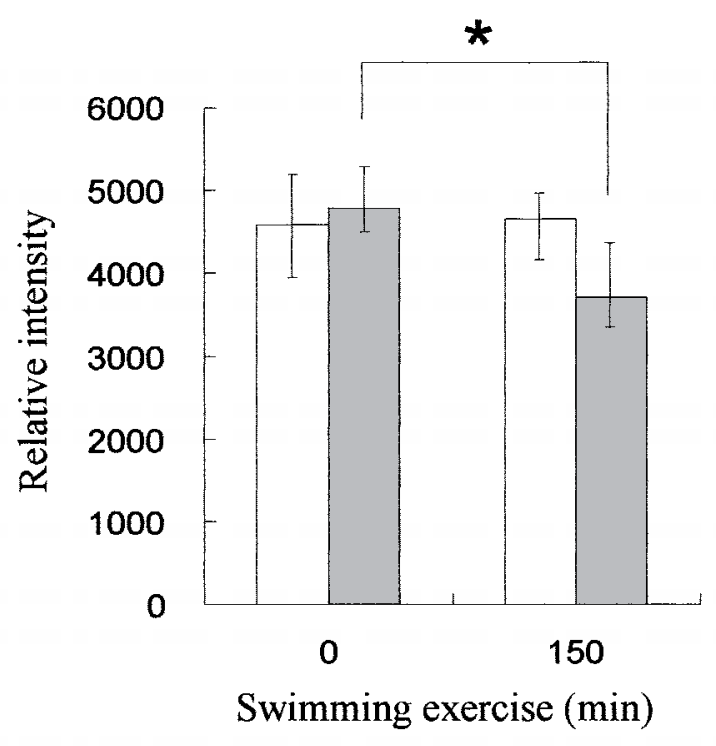

Fig. 1 Silver-stained two dimensional gels derived from gastrocnemius muscles. Gastrocnemius muscles of control mice and of swim-exercised mice (150 $\mathrm{min})$ were analyzed by using two dimensional gels. Fig. $1 \mathrm{~A}$ and $1 \mathrm{~B}$ show silver-stained gels derived from gastrocnemius muscles of control mice and of swim-exercised mice, respectively. The arrow shows a spot whose protein expression (Al854635) was remarkably decreased. To confirm the results of two dimensional gel experiment, RT-PCR was performed using total RNA derived from control and swim-exercised (150 min) mice. The mRNA expression data of the Al854635 and GAPDH (control) are shown in Fig. 1C, and the quantitative data are shown in Fig. 1D (mean \pm $\mathrm{SD}, \mathrm{n}=3$ ). Statistical significance was obtained between swim-exercised and control mice $\left({ }^{*} \mathrm{P}<0.05\right)$. 100 bp DNA ladder was used as a DNA marker. 

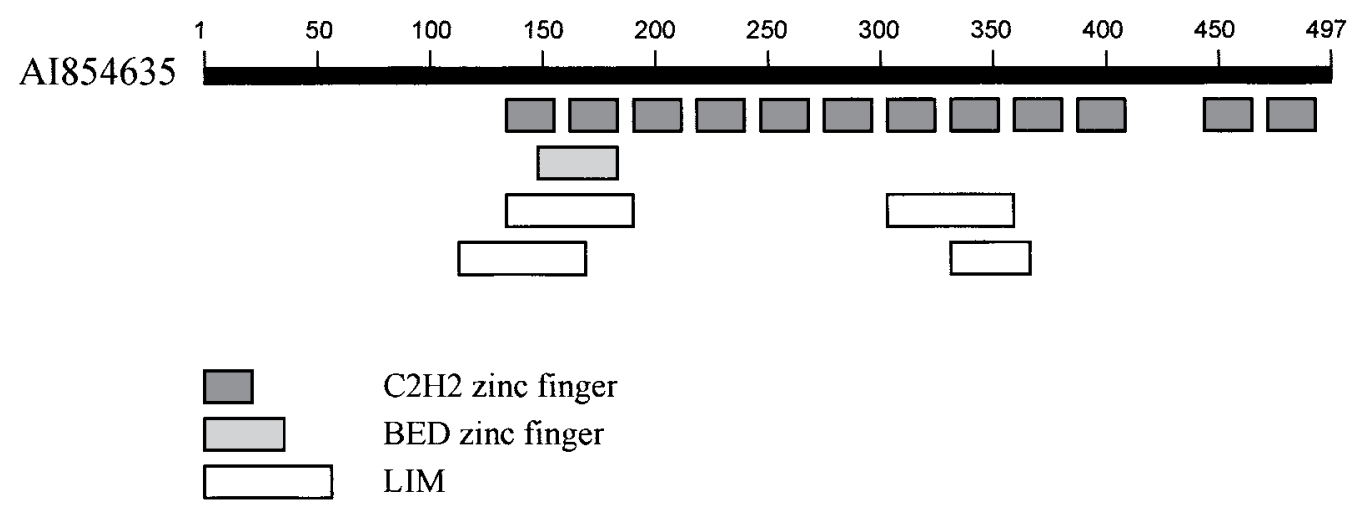

Fig. 2 Domain search of Al854635. Domain search was performed using the NCBI Conserved Domain Search Program. A putative amino acid sequence of the Al854635 (497 amino acids) was applied to the program. The Al854635 has $12 \mathrm{C} 2 \mathrm{H} 2$ type zinc finger domains, 1 BED zinc finger domain and 4 LIM domains.

between controls and exercised mice. Although we analyzed 9 spots using the mass spectrometry as described in Materials and Methods, only two spots could be identified. One of the five spots whose expression was increased was identified as cytoplasmic dynein. One of the four spots whose expression was decreased was identified as functionally unknown "expressed sequence AI854635 (NM_177565)" gene (as indicated by an arrow in Fig. $1 \overline{\mathrm{A}})(20,22)$. To confirm the result of two dimensional gel electrophoresis, we performed RT-PCR using total RNA derived from control and swim-exercised mice. As shown in Fig. 1C and 1D, the AI854635 mRNA expression of swim-exercised mice was significantly decreased, compared to control mice.

\section{Domain search of AI854635 gene}

We next performed domain search using the NCBI (National Center for Biotechnology Information) Conserved Domain Search Program. A putative amino acid sequence of the AI854635 (497 amino acids) was applied to the program. As shown in Fig. 2, the AI854635 has $12 \mathrm{C} 2 \mathrm{H} 2$ type zinc finger domains, 1 BED zinc finger domain and 4 LIM domains. Thus, the AI854635 is considered to be a transcription factor. Several transcription factors such as ZT2, ZT3, KRAB, and MDZF proteins have $\mathrm{C} 2 \mathrm{H} 2$ zinc finger domains $(5,8,16,27)$.

mRNA expression levels of AI854635 gene in various tissues

The mRNA expression levels of AI854635 gene in various tissues of mice were analyzed using semiquantitative RT-PCR. The conditions for RT-PCR are shown in Table 1. The tissues analyzed were gastrocnemius muscle, soleus muscle, heart, thymus, brain, kidney, spleen, and liver. As shown in Fig. 3, the mRNA expression levels of AI854635 gene were relatively high in skeletal muscle, brain, kidney and thymus. We next studied whether it is involved in myoblast differentiation.

$m R N A$ Expression of AI854635 gene during C2C12 myoblast differentiation

To elucidate the function of the AI854635 gene we studied mRNA expression levels during $\mathrm{C} 2 \mathrm{C} 12$ myoblast differentiation. $\mathrm{C} 2 \mathrm{C} 12$ cells started differentiation upon a reduction of the serum content in culture media, as has been reported (4). Fig. 4 shows morphological alteration during $\mathrm{C} 2 \mathrm{C} 12$ myoblast differentiation under a phase-contrast microscope. $\mathrm{C} 2 \mathrm{C} 12$ began to form myotube around $20 \mathrm{~h}$ after the initiation of differentiation upon a reduction of serum by switching from DMEM containing $10 \%$ fetal calf serum to DMEM containing $2 \%$ horse serum.

Figs. $5 \mathrm{~A}, \mathrm{~B}, \mathrm{C}$ and $\mathrm{D}$ show a time course (from $0 \mathrm{~h}$ to $48 \mathrm{~h}$ ) of mRNA expression levels of GAPDH, myogenin, Myf-5 and AI854635 genes during myoblast differentiation, respectively. The GAPDH gene expression was used as a control. The mRNA expression levels of AI854635 gene was significantly induced around $6 \mathrm{~h}$ and increased till $48 \mathrm{~h}$, indicating a pivotal role in myoblast differentiation. The mRNA expression levels of myogenin was significantly induced from $20 \mathrm{~h}$ to $48 \mathrm{~h}$. The Myf-5 expression levels were unchanged from $0 \mathrm{~h}$ to $36 \mathrm{~h}$. The MyoD expression levels were low from $0 \mathrm{~h}$ to $36 \mathrm{~h}$ (data not shown). The data suggest that AI854635 gene expression was induced prior to myogenin induction, and was involved in $\mathrm{C} 2 \mathrm{C} 12$ myoblast differentiation, especially during earlier 
A

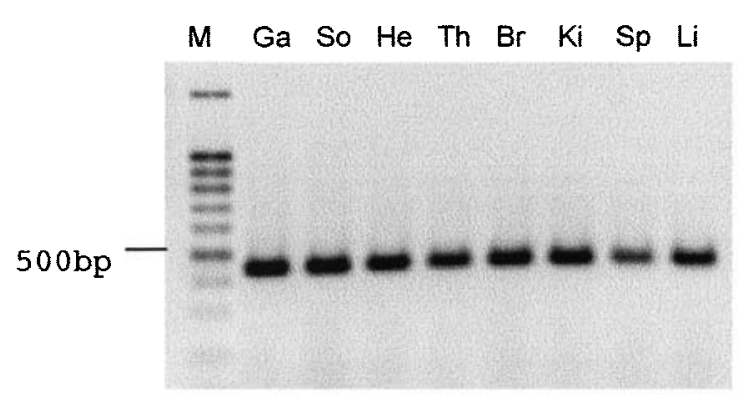

B

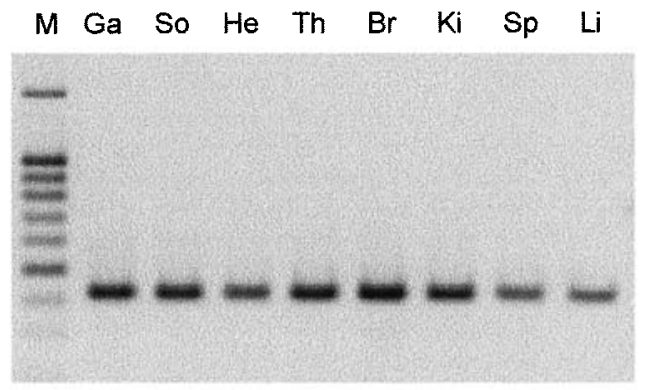

Fig. 3 The expression level of Al854635 in various tissues. The mRNA expression of Al854635 gene was analyzed using semi-quantitative RT-PCR. The PCR products were analyzed using $2 \%$ agarose gels. The tissues used were gastrocnemius muscle $(\mathrm{Ga})$, soleus muscle (So), heart $(\mathrm{He})$, thymus (Th), brain $(\mathrm{Br})$, kidney (Ki), spleen (Sp), and liver ( $\mathrm{Li})$. A 100 basepairs DNA ladder was used as a DNA size-marker. A. GAPDH mRNA expression, B. Al854635 mRNA expression

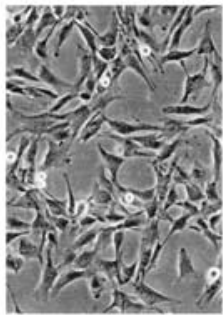

$\mathrm{Oh}$

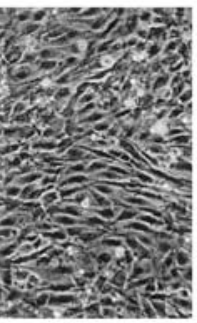

$20 \mathrm{~h}$

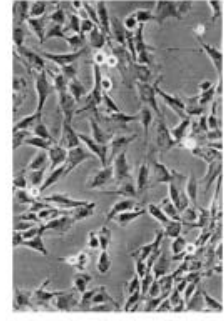

$3 \mathbf{h}$

Differentiation $(\mathrm{h})$

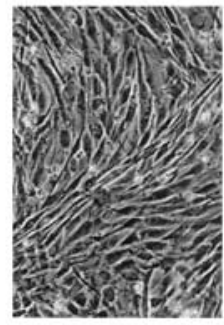

$36 \mathrm{~h}$

Differentiation (h)

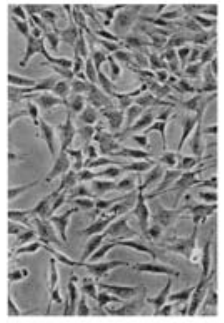

$9 \mathrm{~h}$

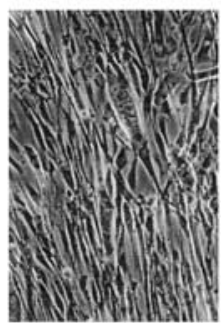

$48 \mathrm{~h}$
Fig. 4 Morphological alteration during $\mathrm{C} 2 \mathrm{C} 12$ myoblast differentiation. Morphological alteration during C2C12 myoblast differentiation was visualized under a phase-contrast microscope $(\times 100)$. C2C12 began to form myotube around $20 \mathrm{~h}$ after the initiation of differentiation upon a reduction of serum.

step of differentiation.

\section{DISCUSSION}

In the present study we analyzed alterations of protein expression in mouse gastrocnemius muscles in- duced by exercise (150 min swimming exercise) using proteomics techniques. One of the four decreased protein spots was identified as functionally unknown AI854635 gene $(20,22)$. A putative amino acid sequence of the AI854635 (497 amino acids) was applied to the domain search program, and we found that the AI854635 has $12 \mathrm{C} 2 \mathrm{H} 2$ type zinc finger domains, 1 BED zinc finger domain and 4 LIM domains. Several transcription factors such as ZT2, ZT3, KRAB, and MDZF proteins have $\mathrm{C} 2 \mathrm{H} 2$ zinc finger domains $(5,8,16,27)$. Thus, the AI854635 is considered to be a transcription factor. In addition, the AI854635 is abundantly expressed in muscle. Therefore, we tested whether this gene is involved in myogenic differentiation using myoblast $\mathrm{C} 2 \mathrm{C} 12$ cell differentiation system (4). We found that the mRNA expression of the AI854635 gene was significantly induced around $6 \mathrm{~h}$ prior to the induction of myogenin mRNA expression (from $20 \mathrm{~h}$ ), suggesting a pivotal role during earlier step of myoblast differentiation.

There are several reports that exercise activates satellite cells in mature skeletal muscle cells and induces their differentiation leading to skeletal muscle cell hypertrophy $(2,6,17)$. Exercise also increases myogenin protein expression (17), which indicates a close link between exercise and skeletal muscle differentiation. In contrast to myogenin, the mRNA expression of the AI854635 gene was decreased after swimming exercise. Although the reason for the difference between myogenin and AI854635 gene expression is not clear, there are two possibilities. One is that decreased expression of the AI854635 gene induced by exercise is irrelevant to skeletal muscle cell hypertrophy in vivo. Another one is that de- 
A
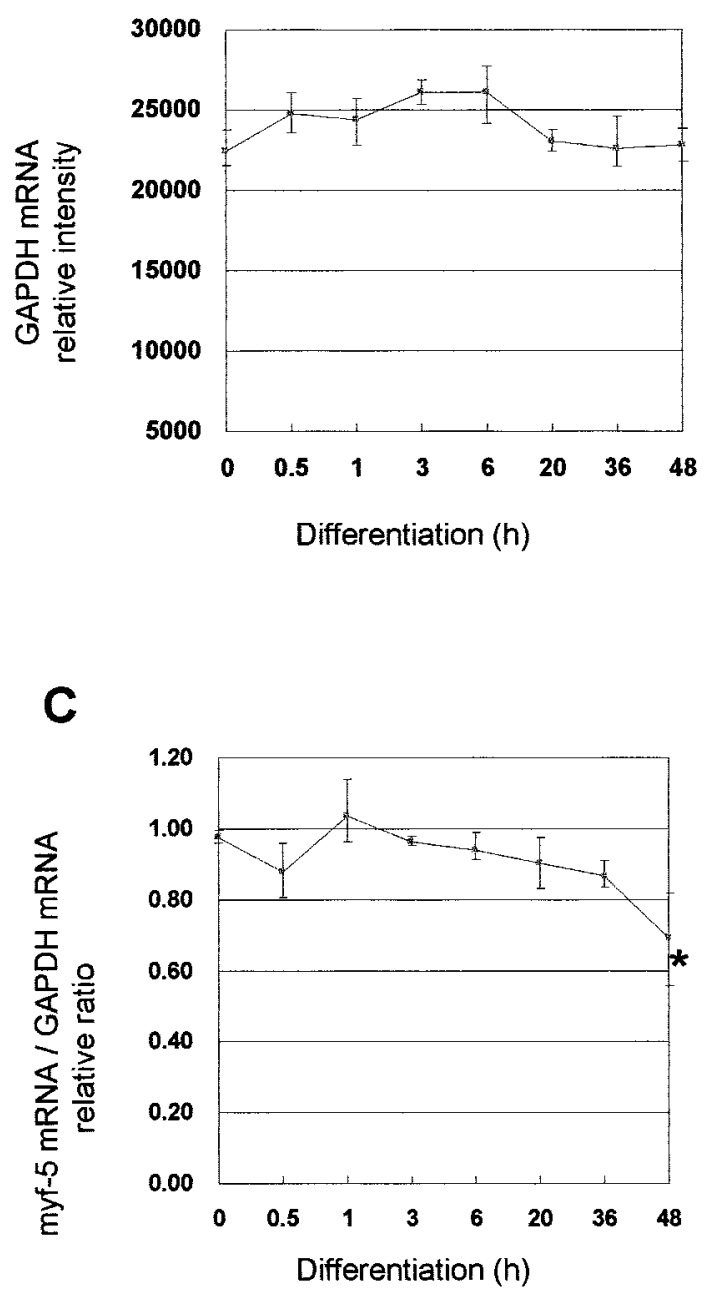

B
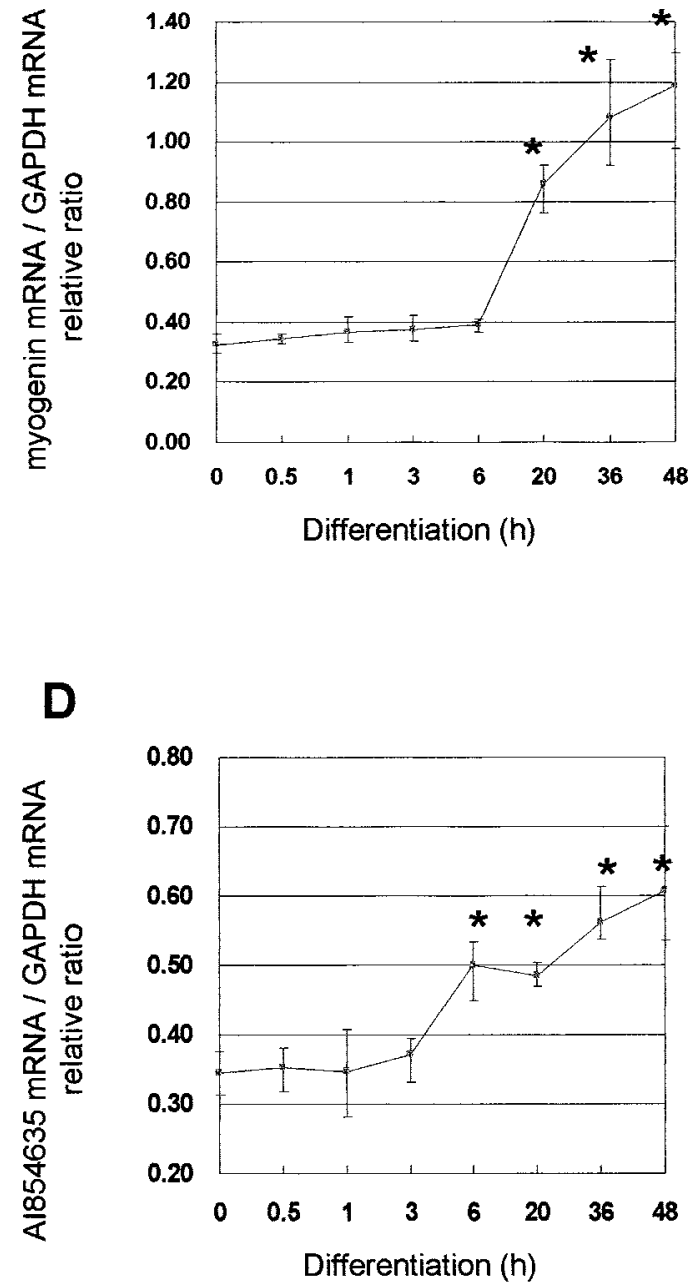

Fig. 5 mRNA expression levels of the Al854635 during myoblast differentiation. Time course (from $0 \mathrm{~h}$ to $48 \mathrm{~h}$ ) of mRNA expression levels of the myogenin, Myf-5 and Al854635 genes during myoblast differentiation was studied using C2C12 myoblast differentiation system in vitro $(n=3)$. The levels of mRNA expression of these genes were analyzed using RTPCR. Using ChemiDoc installed applications the quantity of the PCR products were measured and expressed as pixel counts as described in Materials and Methods. The expression levels were corrected using the levels of GAPDH mRNA expression. Significance of mRNA expression levels compared to $0 \mathrm{~h}$ was evaluated using Student's $t$ test. ${ }^{*} \mathrm{P}<0.01$

creased expression of the AI854635 gene may indirectly lead to skeletal muscle cell hypertrophy in vivo. In the near future we plan to investigate to elucidate the mechanism for explaining the latter possibility. In summary, we found that the AI854635 gene is involved in myoblast differentiation using cultured $\mathrm{C} 2 \mathrm{C} 12$ myoblast in the present study, although the significance of decreased expression of AI854635 gene induced by swim-exercise is unknown.

\section{Acknowlegements}

This study was supported by a grant under the Ministry of Education, Science, Sports, and Culture, Japan.

\section{REFERENCES}

1. Blau HM, Pavlath GK, Hardeman EC, Chiu CP, Silberstein L, Webster SG, Miller SC and Webster C (1985) Plasticity of the differentiated state. Science 230, 758-766.

2. Cameron-Smith D (2002) Exercise and skeletal muscle gene expression. Clin Exp Pharmacol Physiol 29, 209-213. 
3. Cordwell SJ, Wilkins MR, Cerpa-Poljak A, Gooley AA, Duncan M, Williams KL and Humphery-Smith I (1995) Crossspecies identification of proteins separated by twodimensional gel electrophoresis using matrix-assisted laser desorption ionisation/time-of-flight mass spectrometry and amino acid composition. Electrophoresis 16, 438-443.

4. Delgado I, Huang X, Jones S, Zhang L, Hatcher R, Gao B and Zhang P (2003) Dynamic gene expression during the onset of myoblast differentiation in vitro. Genomics 82, 109121.

5. Giorgi S, Polimeni M, Senni MI, De Gregorio L, Dragani TA, Molinaro M and Bouche M (1999) Isolation and characterization of the murine zinc finger coding gene, ZT2: expression in normal and transformed myogenic cells. Gene 230, 81-90.

6. Hill M, Wernig A and Goldspink G (2003) Muscle satellite (stem) cell activation during local tissue injury and repair. $J$ Anat 203, 89-99.

7. James P, Quadroni M, Carafoli E and Gonnet G (1993) Protein identification by mass profile fingerprinting. Biochem Biophys Res Commun 195, 58-64.

8. Jheon AH, Ganss B, Cheifetz S and Sodek J (2001) Characterization of a novel $\mathrm{KRAB} / \mathrm{C} 2 \mathrm{H} 2$ zinc finger transcription factor involved in bone development. J Biol Chem 276, 18282-18289.

9. Molkentin JD, Black BL, Martin JF and Olson EN (1995) Cooperative activation of muscle gene expression by MEF2 and myogenic bHLH proteins. Cell 83, 1125-1136.

10. Montarras D, Chelly J, Bober E, Arnold H, Ott MO, Gros F and Pinset C (1991) Developmental patterns in the expression of Myf5, MyoD, myogenin, and MRF4 during myogenesis. New Biol 3, 592-600.

11. Montarras D, Pinset C, Chelly J, Kahn A and Gros F (1989) Expression of MyoD1 coincides with terminal differentiation in determined but inducible muscle cells. $E M B O J \mathbf{8}, 2203$ 2207.

12. Olson EN and Klein WH (1994) bHLH factors in muscle development: dead lines and commitments, what to leave in and what to leave out. Genes Dev 8, 1-8.

13. Ott MO, Bober E, Lyons G, Arnold H and Buckingham M (1991) Early expression of the myogenic regulatory gene, myf-5, in precursor cells of skeletal muscle in the mouse embryo. Development 111, 1097-1107.

14. Pappin DJ, Hojrup P and Bleasby AJ (1993) Rapid identification of proteins by peptide-mass fingerprinting. Curr Biol 3, 327-332.

15. Perry RL and Rudnick MA (2000) Molecular mechanisms regulating myogenic determination and differentiation. Front Biosci 5, 750-767.

16. Polimeni M, Giorgi S, De Gregorio L, Dragani TA, Molinaro M, Cossu G and Bouche M (1996) Differentiation dependent expression in muscle cells of ZT3, a novel zinc finger factor differentially expressed in embryonic and adult tissues. Mech Dev 54, 107-117.

17. Psilander N, Damsgaard R and Pilegaard H (2003) Resistance exercise alters MRF and IGF-I mRNA content in human skeletal muscle. J Appl Physiol 95, 1038-1044.
18. Rudnicki MA, Schnegelsberg PN, Stead RH, Braun T, Arnold HH and Jaenisch R (1993) MyoD or Myf-5 is required for the formation of skeletal muscle. Cell 75, 1351-1359.

19. Sabourin LA and Rudnicki MA (2000) The molecular regulation of myogenesis. Clin Genet 57, 16-25.

20. Strausberg RL, Feingold EA, Grouse LH, Derge JG, Klausner RD, Collins FS, Wagner L, Shenmen CM, Schuler GD, Altschul SF, Zeeberg B, Buetow KH, Schaefer CF, Bhat NK, Hopkins RF, Jordan H, Moore T, Max SI, Wang J, Hsieh F, Diatchenko L, Marusina K, Farmer AA, Rubin GM, Hong L, Stapleton M, Soares MB, Bonaldo MF, Casavant TL, Scheetz TE, Brownstein MJ, Usdin TB, Toshiyuki S, Carninci P, Prange C, Raha SS, Loquellano NA, Peters GJ, Abramson RD, Mullahy SJ, Bosak SA, McEwan PJ, McKernan KJ, Malek JA, Gunaratne PH, Richards S, Worley KC, Hale S, Garcia AM, Gay LJ, Hulyk SW, Villalon DK, Muzny DM, Sodergren EJ, Lu X, Gibbs RA, Fahey J, Helton E, Ketteman M, Madan A, Rodrigues S, Sanchez A, Whiting M, Madan A, Young AC, Shevchenko Y, Bouffard GG, Blakesley RW, Touchman JW, Green ED, Dickson MC, Rodriguez AC, Grimwood J, Schmutz J, Myers RM, Butterfield YS, Krzywinski MI, Skalska U, Smailus DE, Schnerch A, Schein JE, Jones SJ and Marra MA; Mammalian Gene Collection Program Team (2002) Generation and initial analysis of more than 15,000 full-length human and mouse cDNA sequences. Proc Natl Acad Sci USA 99, 16899-16903.

21. Tapscott SJ and Weintraub H (1991) MyoD and the regulation of myogenesis by helix-loop-helix proteins. J Clin Invest 87, 1133-1138.

22. The FANTOM Consortium and the RIKEN Genome Exploration Research Group Phase I \& II Team (2002) Analysis of the mouse transcriptome based on functional annotation of 60,770 full-length cDNAs. Nature 420, 563-573.

23. Vierck J, O'Reilly B, Hossner K, Antonio J, Byrne K, Bucci L and Dodson M (2000) Satellite cell regulation following myotrauma caused by resistance exercise. Cell Biol Int 24, 263-272.

24. Wasinger VC, Cordwell SJ, Cerpa-Poljak A, Yan JX, Gooley AA, Wilkins MR, Duncan MW, Harris R, Williams KL and Humphery-Smith I (1995) Progress with gene-product mapping of the Mollicutes: Mycoplasma genitalium. Electrophoresis 16, 1090-1094.

25. Weintraub H (1993) The MyoD family and myogenesis: redundancy, networks, and thresholds. Cell 75, 1241-1244.

26. Yaffe D and Saxel O (1977) Serial passaging and differentiation of myogenic cells isolated from dystrophic mouse muscle. Nature 270, 725-727.

27. Yuan Z, Huang X, Zhang W, Zhang $M$, Wan $T$ and Cao X (2001) Cloning and characterization of a novel zinc finger protein (MDZF) that is associated with monocytic differentiation of acute promyelocytic leukemia cells. J Cancer Res Clin Oncol 127, 659-667.

28. Zhou M, Lin BZ, Coughlin S, Vallega G and Pilch PF (2000) UCP-3 expression in skeletal muscle: effects of exercise, hypoxia, and AMP-activated protein kinase. Am J Physiol Endocrinol Metab 279, 622-629. 